\title{
看護職者の学習要求を形成した体験と意識の調查研究 一編入学教育に生かす学習者特性の課題一
}

\author{
平 河 勝 美*1
}

\section{Investigation in Nurses' Experience and Consciousness as The Formative Factor of The Learning Needs: Educational Issues Dealing in The Learner's Characteristic of The Nurses}

\author{
Katsumi HIRAKAW A*1 \\ ${ }^{* 1}$ Graduate School of Education, Kobe University
}

\begin{abstract}
Abstact
The purpose of this study is to investigate nurses' experience and/or consciousness that have formed their learning needs and their desire to enter the baccalaureate course of nursing, in order to investigate the adequacy of RN/BSN course. 22 nurses who have graduated from junior colleges and have desire to learn more under a RN/BSN program are interviewed.

The analytical focus is placed on the relationship between two kinds of consciousness; fundamental consciousness/experience of the learning needs, and self-consciousness. The findings are as follows: 1) All subjects are classified into 3 types according to the categories of consciousness in which they fall, mainly due to the difference of their aims and/or their learning needs.

2) The first group, "external", includes 13 subjects who show intense concern over their daily nursing practice.

3) The second group, "intersubjective”, includes 5 keen observers of contrasts between patients and themselves.

4) The last group, "internal”, includes 4 subjects who feel stronger needs for self-improvement than for professional training.

5) As an educational issue, it is the perspective of the nurse-as-learner that teachers in charge of RN/BSN course have to understand.

Two conclusions emerge out of these findings. 1. Teachers are recommended to sympathise with the nurses' balance of social and individual consciousness, which has formed through nursing experience and/or daily life. 2. RN/BSN course ought to include some programs to correct nurses' tendency that set the valuation at rather lower level, around their own nursing capability .
\end{abstract}

要 旨

本研究の目的は, 編入学教育の構想に資するための, 看護職者の学習要求を形成してい る体験や意識の明確化である。

調査対象は編入学資格を有し，それを志望している看護職者 22 名であり，調査方法は半 構成的面接法である。調査内容は編入学を志向するに至った経緯, 印象的だった看護体験

*1 神戸大学大学院教育学研究科修士課程 
や生活体験などとし, その中から, 編入学志向の根底にあると解釈される意識と自己意識 との関連性を分析点とした。

対象者は 3 群に分類された。それらは，日常の看護実践に関する課題意識が特徵である 「外在」群, 他者之の関係や相互理解に関心の強い「間主観」群, 自己陶冶や省察の要求 が特徵的な「内在」群である。また, 編入学教育者が追認すべき要素として, 学習要求を 形成する意識の中の “社会” “ “自己” の比重とその変動, 看護実践能力の不足感が形成 する能力観や自己能力評価などが確認できた。

\section{はじめに}

教育とは, 人間の尊厳を重んじ，その人格完 成を意図して働きかけるいとなみである ${ }^{1) 。 し ~}$ たがって教育者には学習者の人権と人格を尊重 する態度が求められる。例えば，学習者を教育 の客体と捉えて対面的に向き合うだけでなく， 学習の主体と捉えて同方向的に追随する姿勢な どである。

学習とは, 何らかの知見の吸収や再創造によっ て内面に長期的な変容を起こす過程である。学 習は教育と異なり，意図性や系統性を必ずしも 要しない。日常生活体験によっても人間は偶発 的に何かを学習し, その結果内面的にいくらか 変容している。生命現象と生活現象は学習の母 体である2)。

以上を踏まえて看護系大学の編入学教育を考 えると, 編入学生の人格は編入学以前の様々な 体験が育成した存在であり, 教育者は編入学生 の人格を了解して教育構想に反映させなければ ならない。そのためには, 看護診断について学 びたいとか心理学をやりたいなど表面的な学習 要求に止まらず, その根底にある意識の様態が 現実的課題となる。しかし大半の編入学課程が 漸くこの数年間に設置され始めたばかりであり, 看護教育界はこの課程の経験知を広く共有する には至っていない。この分野の研究成果 ${ }^{3 \sim 5}$ を端緒に，この課題に対する経験の途を歩み出 したところである。

\section{研究目的}

本研究の目的は, 編入学を志望している看護 職者の学習要求がどのような体験あるいは意識 から形成されているのかを明らかにすることで
ある。つまり学習要求を多角的多層的に読及解 くことを主旨としている。学習要求を形成する のは学習者の主体であり，その主体自身が意識 作用の対象となる自己意識は学習要求理解にとっ て重大な鍵となる。本研究はこの点に立脚して 構想したものである。

\section{調査方法}

調査対象は, 短期大学を卒業して兵庫県の県 立病院に勤務している看護職者であり，この調 査に先立って実施した学習要求に関する質問紙 調査 ${ }^{6)}$ によって編入学志望者であると確認でき た37名から抽出した 22 名であった。編入学志望 者のみを対象としたのは, 編入学といら学習行 動を起こす可能性が高く, 教育課題としての現 実性が裏付けられやすいためである。なお，短 期大学は看護系に限定していない。

対象者には質問紙調査前に研究目的, 面接調 査を依頼する可能性, プライバシー保護につい て書面で説明していたが，本調查依頼時に拒否 する権利も含めて口頭で確認を取った。調査方 法は半構成的面接法を用い, 対象者の了承を得 て面接内容を録音した。

主な質問内容は, 編入学志向に至った動機や 経緯, 印象に残っている看護体験や生活体験, 学習要求の具体的内容, 編入学に関する認識と した。時間的制約を考慮し, 編入学志望に至っ た経緯や動機から質問を開始した。面接所要時 間は平均55分であった。

調査時期は平成 6 年11月から 7 年 1 月であっ た。

分析にあたっては録音された面接内容を逐語 的に書き起こし，話し言葉の一文は必ずしも明 確でないので分析単位を文節ないしは文章とし 
た。そして意味内容の区切りごとにコード化し た後, 全コードを比較検討, 整理した。また, 分析の一貫性のために約 6 力月後に再分析した。

今回の報告にあたり, 以上の分析結果から, (1)編入学志向の根底にあると解釈される意識, (2)生育歴や性格特性などの自己意識を抽出した。 次に，(1)と(2)の間の何らかの関連が語られてい たか, 面接全体を通して主に語られていた内容 は何かなどを参考にして(1)と(2)の関連性を調 ベた。

\section{結果}

\section{1. 対象者の特性}

対象者は男性 1 名, 女性 21 名で, 既婚者は 4 名であった。看護の臨床経験年数は平均 5.6 年 であった。

卒業した短期大学で見ると, 看護系 3 年課程 卒業者 19 名, 看護系 2 年課程卒業者 2 名, 看護 系以外の短期大学卒業者 1 名であった。役職で は主任 1 名と婦長 1 名が含まれていた。

\section{2. 編入学志向の根底にある意識と自己意識と の関連性}

分析の結果, 編入学志向を根底で支㝋ている と解釈された意識として，「学習時間のゆとり への欲求」「研究に関する意欲」「より良い看護 実践の追求」「職業移動・職場移動に対する抵 抗感のなさ」「学歴の劣等感」「短大時代とは違 ら学びがでさる自信」など44のコードが抽出さ れた。自己意識としては「プラス思考」「負け ず嫌い」「意見・意志表現の乏しさ」「看護実践 を通じた自己変容の実感」など28のコードが抽 出された。

前者の意識と後者の自己意識との関連性には, 対象者ごとに強弱が読み取れた。そこで各対象 者ごとに自己意識の範囲を仮定し, 編入学志向 を根底で支觉る意識が主にその範囲の外にある と思われる対象者を「外在」群とした。同様に， 主に自己意識の範囲の内にあると解釈された者 を「内在」群とした。また，他者意識が重要な 鍵になっていてこれら 2 群に該当しにくい者を 「間主観」群として, 全対象者を 3 群に分類し た。
以下に各群ごとに対象者の意識の特徵と構造 図を，典型的な実例を含めて報告する。

\section{1)「外在」群}

この群の対象者の編入学志向の根底にある意 識は, 看護実践改善への模索, 大学教育に対す る期待，新たな資格取得と活用などに集中する 傾向にあった。他方, 自己意識は比較的表現さ れなかった。この群に分類されたのは13名であっ た(図 1 )。

\section{[事例 A]}

「解剖と病理と生化学だけはしないと, 患者の 状態が把握できないことだらけなんですよ。患 者と話して身体を拭いたり，そらいらケアも大 事になってくるけど，集中治療室では医者より 先に患者の変化に結び付けていかないと。肝蔵 が悪いからこらなって今の症状に表れているっ ていらのを，逆から見ていったり。そらいらこ とが望まれている。それがわからないまま動い ているのが，すごく辛い時がある。勉強すれば 良いんでしょらけど，莫大な量ですよ初。学生 の時にやっておけば，今本を開いている時間に 別のことができたんじゃないかと思らことがあ ります。特に看護診断が。解剖や病態生理や生 化学がわかっていれば全部答兄られる。だから 看護診断が出てきて余計思らようになったんで す」

\section{[事例 B]}

「薬一つにしてもその使い方とか，その子のデー タによって看護も全然変わるし, 対処方法も違 ら。でもそれって，皆一緒にできるって思って たから，何か同じよらに考㝋ていたら，それ違 らって言われて。最近，女の子でステロイドの 多量療法で精神的ダメージすごい受けてしまっ て。そんなのは全然。ステロイドで精神的ダメー

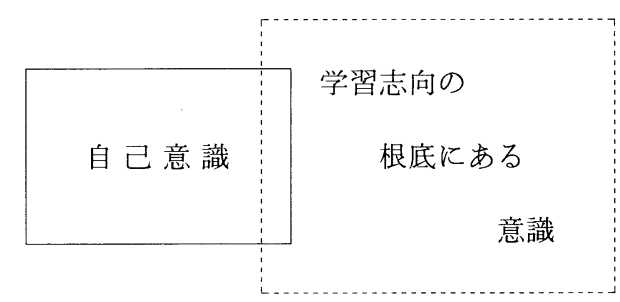

図 1 「外在」群に分類された 対象者13名の意識の構造 
ジ受けるのは聞いてたけど，実際こんなのは全 然イメージできなかったし，どうしたらいいの か全然出てこない。実際, どうしたらいいのか。 初めて自分で何か勉強したいっていらのが。結 構最近。何年かしたら。最初は仕事覚光るので 必死だったけど，何年かしてそらいうのが出て くる」

\section{[事例 C]}

「その人にとっては看護婦がいないと回復して 行けないけれども, 大きな流れの中で, まず, ドクターの意思がないと進まない。この人はこ の治療を望んでいるのかなって, 誰が見ても無 駄なこと，何週間か何時間か命を延ばしてどう なるんだろらといらような, 処置や治療があり ますよね。そらいらのがわかってしまらと， (ドクターに)従って, 逃げのもとで仕事してい くのが看護婦なのかなと」

事例 $\mathrm{A}$ と B は, 臨床看護に従事して改めて看 護実践にどのような知識と能力が必要なのかを 発見し，自分にはそれらが不十分だと気付いて いる。そしてこの気付きが学習活動を志向する 原動力となっている。このように看護実践の根 拠となる知識や論理的思考能力などを獲得した いといら体験や意識を有している者は, この群 の大半を占めていた。他方, 事例 C 2 医師との 関係性の中で看護独自の役割機能の限界を感じ, 強く失望したことが学習活動を志向する動機に なっている。

\section{2)「間主観」群}

この群の対象者は, 編入学志向の根底にある 意識と自己意識の他に, 看護実践で出会ら他者 の存在と人格, 及び人間関係を重点的に意識し ていた。意識が自己の外側に向かっている点で は「外在」群と共通しているが，他者意識を加 えた間主観性に特徵があった。他者として語ら れていたのは全て患者であり，この群には 5 名 が属していた(図 2 )。

[事例D]

「その子の体験していることとか少しは理解で きるけど, 複雑ですから。家庭環境も結構あっ たり。勉強してきた心理学は自分と置き換えて

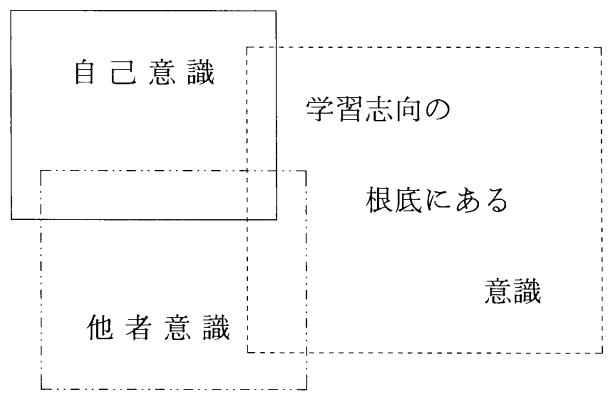

図 2 「間主観」群に分類され た対象者 5 名の意識の構造

いたんで。患者はまた複雑なので。他の人と話 して初めて理解でさることも多くて，それも学 問的だったりそらでなかったりしますけど。取 り組んでできない部分もあるから，その子の看 護をでは至らなかったことはあります。その子 が成長して変わっていくのを長い目で見なくて はいけない部分もあるし，自分が傷つくのも怖 いし，その子を傷つけても変えられないかもし れないし，当たらず触らずですね。チーム看護 ではしてはいけない部分も出てきて, 自分も引 いてしまう方なんで, 仕方ないんです」

[事例 E]

「患者と言い合いして涙流して帰ってくること もあったんですけど, 患者の立場が理解できるっ て言らか，言わざるを得ない状沉なんだなって わかって。それは感情的な部分なんですよね。 自分が怒るといらのも感情だなって。怒った原 因を自分の中で探して，私はこういうところを 言われると怒るなっていらのがわかれば，次の 対応の時には衝突が少なくて。違ら看護婦も行 くので，その時はそれなりに患者も違らケアも 受けられる」

事例 Dは環境要因などを含めて患者を了解す る難しさを, 事例 $\mathrm{E}$ は患者と自分の対比から両 者を了解する有益さを意識している。また，ぞ ちらもチーム看護に言及しているが，その意識 の方向性には興味深い相違が認められる。事例 Dはチームが自分の実践に制限を加える側面を

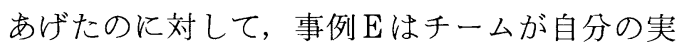
践を補充する側面をあげたのである。 
3 )「内在」群

この群では, 対象者の編入学志向の根底にあ る意識は看護の課題ではなく，むしろ自分の人 生に対する課題意識が直接的に編入学志向を形 成していた。この群に分類されたのは 4 名であっ た(図 3 )。

\section{[事例 F]}

「自分を高めたい気持ちは強いんですよ。今の ままでいいのか。今は変化を求めてる時期なの で。吸収したい気持ちで変化を求めている。新 しいことにチャレンジしたい，新しい何かを吸 収したい。極めることも大事だけれども何か新 しいものを吸収しないとこれ以上極号ない， みたいな。能力的には限界も感じてるから。然 え尽きじゃないんですよ，全然。もっと貪欲な んです。自分にプラスになるものが欲しい」 [事例 G]

「(短期大学に括ける看護の学習が)職業にも役 だってるし，同僚との関係とか他の職業の人と の関係とか考㝋ると，役立ってる。看護概論及 たいな，看護論みたいなのでしょらかね。あの 勉強をしてなかったら，今の自分はさっとこん なではないだろらなといら，自分の伸びたかな と思らところがなかったやろな，とは。育って きた環境も大きいと思うんですね。らちの親は マイナス志向で, 考方方が。で, 小さい時から その影響を受けてるなと。学生時代も(アルバ イト先で)じっとしていてコッコッ自分だけの 仕事に拘っていたのは，そらいう影響を受けて たん違らかなと思うんですよ。それは今になっ て思えば，なんですけど。でもこの職業につい てこらいら勉強をした時に，まだ多少は（親の 影響が)残ってる，多少じゃなくて大分残って るし，友だちにそら言われる時もあるんですけ

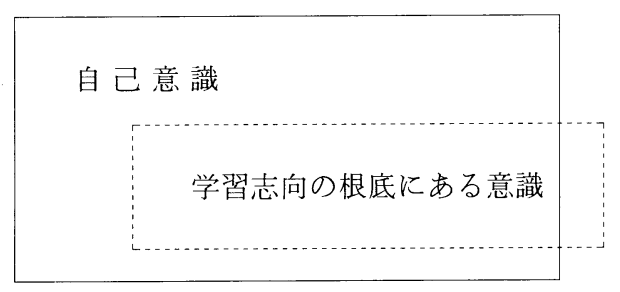

図 3 「内在」群に分類された 対象者 4 名の意識の構造
ぞ，それでも自分の中では，長い20何年間生き てきた中では，変わったところも多少はあるん でね。友だちには気付いてもらえない変わった ところっていらのは, 学校の勉強が大きかった かなといら気がしますね」

事例 $\mathrm{F}$ と $\mathrm{G}$ は共に自己変容について, 事例 $\mathrm{F}$ は未来に向けてのそれを, 事例 $G$ は過去を振り 返ってのそれを意識している。時間的方向性は 異なっているが, 自己変容が教育との関連で意 識されているところは共通している。特に事例 Gは漸く短期大学での学習を意味付けているの であり，教育が人間形成となって結実するのに は時間を要することを示す好例である。

\section{考察}

\section{1. 結果の解釈}

1） 3 群を総括した解釈

編入学志向の根底にある意識と自己意識との 関連性は,「外在」群から「内在」群に向けて 順に “社会化”の程度が減じ, “内面への対峙” の程度が増えていると解釈される。これに対し て“社会”と“自己”を両極とする連続体を想 定してみると，その連続体上の随所から学習要 求に繫がる課題意識が生じていると考えられる。 事例 Dの心理学の活用状態や事例 $\mathrm{G}$ の家庭環境 からの解放など, 各対象者の意識においてはこ の連続体上の様々な部分が相互に関係していた。 つまり，この連続体は全対象者に対して一つ， 各対象者ごとに一つを想定する必要がある。

編入学の教育者には, 教育課題をこの連続体 上でダイナミックに移動させる柔軟な意識が求 められよう。必要に応じて “社会”之“自己” を適宜に焦点化する創造性と均衡意識が教育課 程編成やガイダンスなどに生かされれば，看護 実践を通じて社会参加してきた編入学生の学習 要求により良く適えられるであろら。

\section{2 ) 能力に関する意識}

能力に関して, 事例 $\mathrm{B}, \mathrm{D}, \mathrm{G}$ など, 看護基 礎教育による学習内容と就職後の実践体験を統 合的に意味付けする学習能力が注意を引いた。 他方, 事例 $\mathrm{A} \sim \mathrm{D}$ や F に見られるように，わか 
らない，できないなどの否定的な感覚と編入学 志向の繫がりも注目に值する。この傾向は他の 対象者にも広く認められるものであった。

このように客観的に評価できる高い学習能力 の一方で, 主観的には看護実践能力の不足感が 大きいことが特徴と言えよう。この能力不足感 の背景には実践して得た看護の的確な理解があ るのだろらが，彼らは熟練によって能力を確実 に向上させてもいるはずである。能力向上を適 切に自己評価できていないとすれば，問題であ る。

したがって編入学の教育者は, 看護実践を支 える強い使命感, 実践して生じる疑問や不全感 などを共有し，これらの感性が支持している能 力観を追認，追体験してみなければならない。 編入学生が彼らの能力観と自己能力評価との間 に均衡を保つことが教育課題となろら。

\section{2. リカレント教育としての編入学教育の教育 的価値}

編入学生となるのは離職して教育を受ける看 護職者が多く, 編入学はそのリカレント教育の 場と捉えることができる。

リカレント教育はOECDが提唱した教育戦略 であり，教育を全生涯において労働や余㗇など と交互に分散配置するものである。その理念は 過去の教育機会の不平等を生涯といら時系列の 中で均等化することと, 職業経験と教育を統合 することである。また，リカレント教育を成立 させるのは，教育以外の場面における偶発的な 学習が人間形成にとって極めて重要だという見 識である ${ }^{7)}$ 。

学習の偶発性の例として, 事例 A は集中治療 室に配属されたことを契機にそこで求められて いる看護の特性に気付き, 学習要求を強くして いた。事例 $\mathrm{C}$ は医師の治療方針が自分の医療観 や看護観にそぐわない現状に落胆した結果，そ の意識を学習に結び付けようとしていた。この ような偶発的体験は, 主体性を欠いては “学習” にならない。体験の主体的な取り込みが編入学 生の特性であり, その特性の意味付けが教育課 題となる。

したがってリカレント教育としての編入学の
教育的価值は, 現場体験を学習として積極的に 評価する “脱学校”的な考え万と“学校”とし ての大学教育との統合である。また，その統合 を看護教育が実現する意義も大きいと考える。

\section{3. 成人の発達可能性の問題}

編入学生は年齢的には成人期に該当し，豊か な体験を蓄積しており，その特性は成人性にあ るとも言える。成人性は，一方では認識の枠組 みを頑なに保持する保守性に繫がり，他方では 体験に意味付与して学習を豊かにさせる可能性 にも慗がっている ${ }^{8)}$ 。成人学習者である編入学 生にとって体験から形成された認識枠組みは自 分らしさそのものであり, 彼らが保守化するの は当然の反応である。

編入学生が自己の内面に対峙し省察するには 認識枠組みの変容を伴うことが予想され，それ までに築いた自分らしさを作り直す困難な作業 になると思われる。ここに教育者として追体験 すべき一つの要素として, 編入学生の学習に伴 ら“痛み”があげられよう。事例 F のような自 己変容を強く望む意識は，仮に編入学した場合 に教育課程などを抵抗感なく受け止めるかどう かとは別のものである。動機の強さと意識変容 の可能性とを混同すると, 援助の適切さを欠く ことになる。

教育課題としては, 成人期の発達可能性を信 頼でさるかどらかである。保守化して可能性を 閉ざす場合も含めて, 変容の多様性を認知, 受 容し, 援助することが求められている。成人の 発達は段階的な直線モデルではなく，むしろア イデンティティの危機と確立を繰り返す螺旋モ デルで説明する方が適切だとの指摘 ${ }^{9)}$ は, 編入 学教育にとっても示唆に富むものである。

\section{おわりに}

教育は人間形成の意困性を本質とするため, 学習者の要求と教育意図との “距離”が問題に なる。その距離は, 看護職を選択した15歳ある いは18歳の人々を学習者としている場合と編入 学のように学習者が多様な場合では当然に異質 なものである。その異質さが編入学教育者に專 門性を求めている。要求課題を公共的課題に転 
じるにあたってこの距離に問題意識を抱く限り, 学習者の位置の把握を第一の教育課題とするし かないのである。教育制度としてだけでなく看 護学の教授・学習過程として大学と短期大学の 教育の差異は何か, 編入学課程に抢ける職業教 育と一般教育の両立はどらあるべきかなどの課 題に対し, 今後も学習者特性の視点から取り組 み続けたい。

(本報告は平成 6 年度文部省科学研究費 (奨励研 究 A) の助成による研究成果の一部である)

\section{引用文献}

1 ) 中内敏夫他編著 : 現代教育学の基礎知識 (1), 49, 有斐閣, 1976 .

2 ) 荒瀬豊他：岩波講座現代教育学 1 現代の 教育哲学, 2-8, 岩波書店, 1960 .

3 ) 大賀明子: 看護系大学編入学の実態と看護 教育制度一日本における看護系大学編入学 に関する実態調査から，看護教育，31(1)，
24-32, 1990.

4 ) 河野祐子他: 看護大学編入学生の学習二ー ドに関する実態調査, 聖路加看護大学紀要, No.20, 40-48, 1994.

5 ) 平河勝美 : 看護系大学編入学課程の現状に 関する調査, 看護教育, 35(3), 225-232, 1994.

6 ) 平河勝美他：編入学資格要件を持つ看護者 の学習要求の研究, 日本看護学教育学会誌, 6(1), 53-61, 1996.

7 ) OECD編, 岩木秀夫訳 : リカレント教育, 現代のエスプリ，No.146, 130-140, 1979.

8 ) 永井健夫：認識変容としての成人の学習—J. Mezirow の学習論の検討一, 東京大学教 育学部紀要, 29, 331-339, 1989 .

9 ) 岡本祐子: 成人発達研究の動向と展望, 広 島大学教育学部紀要第 2 部, No.41, 207-216, 1992. 